\title{
Syriac Love Charms. Part I. The Recipe-Type
}

\author{
Anna Cherkashina | ORCID: 0000-0003-4412-4788 \\ Independent scholar, Moscow, Russia \\ tanandajubeo@gmail.com \\ Alexey Lyavdansky | ORCID: 0000-0002-2102-8606 \\ Senior lecturer, HSE University, Moscow, Russia \\ andurar@gmail.com
}

\begin{abstract}
In this paper we consider 6 Syriac love charms and edit their original text and translation. All but two texts are published here for the first time. This is the first part of our inquiry, in which we consider one of the two types of Syriac love charms, the recipe-type. Among its primary characteristics is its extreme rarity in Syriac magic codices. Another prominent trait of this type, which makes these texts especially valuable, is that some of them contain ritual instructions which are exceedingly rare for Syriac charms as a whole, while others may contain what we call an allusion to it. Our assumption is that texts of this type reflect ancient magic practices originating in preChristian time, which are credibly attested in the texts belonging to other magic traditions of the Near East and Egypt.
\end{abstract}

\section{Keywords}

Syriac charms - Eastern Christianity - magic - magic books - erotic magic - Ancient Near East - Aramaic 
Magic practices of Syriac Christians ${ }^{1}$ are represented mostly with handbooks (or codices) dating from the 18 th to the 2oth century. ${ }^{2}$ Though to a lesser extent, Syriac charms are also found on such media as paper and leather scrolls and magic bowls. As argued by Saar, "research on primary sources relating to love magic from the Christian and the Islamic traditions is still in its infancy, like that of Jewish magic". ${ }^{3}$ Although this claim can be easily extrapolated to all Syriac magic texts, by this study we aim to fill the gap in the present knowledge of precisely the love charms found in the Syriac tradition.

This research is a contribution to the project "The Inventory of Syriac Charms" supported by HSE University. ${ }^{4}$ The aim of this project is to compile a comprehensive list of individual charms ${ }^{5}$ within the Syriac tradition of written charms, in order to grasp the whole scope of thematic and pragmatic (functional) variation within this tradition. By the Syriac tradition of charms we understand the corpus of texts in Classical Syriac known to us from the codices and scrolls (rolls, or rotuli) dated from the 18th to the 2oth century. For reasons still to be explored, the core of these texts originate from the Eastern Syriac communities historically located in South-Eastern Turkey (Hakkari, Van), Western Iran (Iranian Azerbaijan) and Northern Iraq. ${ }^{6}$ By individual charm we

1 This work was supported by the Humanitarian Research Foundation of the Faculty of Humanities, HSE University in 2020, Project "The inventory of Syriac charms".

Our deepest gratitude goes to Nikita Kuzin (Freie Universität Berlin) for his diligent assistance during the preparation of this article. Our gratitude also goes to Dr. Yulia Furman for her valuable advice in interpretation of the Syriac text. Likewise we thank Rim Nurullin (HSE University), who provided help cornerning the Mesopotamian parallels. We would also like to show our gratitude to Prof. Matthew Morgenstern (Tel Aviv University), for sharing his pearls of wisdom with us during the course of this research. Last but not least we wish to convey our gratitude to Dmitry Cherkashin (HSE University) for his constant support at all stages of the preparation of this paper.

2 Among the first approaches to the subject are Hermann Gollancz, The Book of Protection, Being a Collection of Syriac Charms, Now Edited for the First Time from Syriac mss., London, 1912; Willis Hatfield Hazard, "A Syriac Charm", Journal of the American Oriental Society, 15 (1893), pp. 284-96; see also Erica C.D. Hunter, "Saints in Syriac anathemas: a form-critical analysis of role", Journal of Semitic Studies, 32/1 (1987), pp. 83-104. For the recent references see Shabo Talay, Stefanie Rudolf and Youssef Kouriyhe, "Ein neues syrisch-aramäisches Amulett", Zeitschrift der Deutschen Morgenländischen Gesellschaft, 170/2 (2020), pp. 289-308.

3 For a brief overview of studies of Jewish, Christian, Mesopotamian and Greek love magic see Ortal-Paz Saar, Jewish Love Magic: From Late Antiquity to the Middle Ages, Leiden, 2017, pp. $17-20$.

4 The description of the project can be accessed through the following link: https://hum.hse .ru/proj/inventar_sirijskih_zagovorov.

5 The term is clarified below.

6 As far as the already published Syriac charms are concerned, all their provenanced manuscript sources point to the Eastern Syriac communities. For references to publications see 
understand a text with its specific function, content and composition, which may be witnessed by a number of copies in various collections of charms. As is usual for the texts existing in multiple hand copies, there is a certain degree of textual variation from copy to copy of an individual charm. One of the main problems for this type of research is to ascertain which text belongs to which (individual) charm. Solving that kind of problem may be shown by the following example. Since the publication by H. Gollancz we know the charm "Binding the mouth of dogs" ('assārā $d-\bar{p} \bar{u} m \bar{e} d-\underline{k} a l b \bar{e}) .{ }^{7}$ There are five more unpublished texts with the same title. ${ }^{8}$ Though three texts in this group may count as copies of the text, published by Gollancz, ${ }^{9}$ the other two texts are different. ${ }^{10}$ While the Gollancz version of this charm is centered upon the symbolism of the stone covering the mouth of the grave of Christ, the alternative version has a historiola of the Holy Family meeting dogs on their way from Egypt. Thus the discussed texts are copies of two distinctive individual charms, having the same title and function, but different in their content and composition. Turning to the charms discussed in this article, some of them have the title $d$-răhmmutta (Text 1 and 2). As will be seen from the contents of those texts, they are totally different in wording and composition, though being of the same purpose.

The charms published here are somewhat specific, all but one ${ }^{11}$ of them are represented by only one copy. It can be assumed that the uniqueness of some texts must be accounted for by the scarcity of the manuscripts at our disposal. Though we managed to study 50 mss. of Syriac charms, which contain a total of about 1500 charms (including copies of the same charm), the real number of Syriac charms mss. ever written must be in the thousands, and a significant part of the written tradition is hidden from the researchers.

Erica C.D. Hunter, "Two Codex Handbooks of Amulets: Mingana ms syr 316 and Rylands ms syr 52", in: Christsein in der islamischen Welt: Festschrift für Martin Tamcke zum 6o. Geburtstag, ed. S.H. Griffith and S. Grebenstein, Wiesbaden, 2015, pp. 423-437. Our research of the manuscript catalogues has shown that there are some collections (handbooks) of charms belonging to the Western Syriac tradition. Nevertheless, none of these texts had ever been published. For references to unpublished Western Syriac "books of protection" see Nicholas al-Jeloo, "Kaldāyūthā: The Spar-Sammāné and Late Antique Syriac Astrology", ARAM 24 (2012), pp. 457-492.

7 Hermann Gollancz, The Book of Protection, p. 15 (Syriac text), p. xxxix (English translation).

8 New York Public Library, syr. 3 (NYPL 3), f. 26v; Houghton Library, syr. 156 (H 156) f. 33v, f. 44v; Institute of Oriental Manuscripts (St. Petersburg), syr. 4, f. 34r-34v; Michail Sado Collection (St. Petersburg), ms. 20, f. 13v.

$9 \quad$ NYPL 3 , f. $26 \mathrm{v} ; \mathrm{H}_{15} 6$ f. 33v, f. $44 \mathrm{v}$.

10 NYPL 3, f. $26 \mathrm{v} ; \mathrm{H}_{15} 6$ f. 33 v, f. $44 \mathrm{v}$.

11 See further in the commentary to Text 6 . 
First, we need to outline what sort of texts we take into consideration before choosing a few which we will include in this study. The category of love charms may encompass texts which seek different goals. Thus, Saar has based her research on Jewish love magic, not only on the texts aiming to induce sexual attraction and preserve or reinforce loving feelings in marriage, but also on the charms for inducing impotence, sowing hate, and obtaining grace and favour with various kinds of people. ${ }^{2}$ Among Syriac charms we can also find these three categories: charms for love and/or attraction, charms for separation and charms for social appreciation. While admitting that these three spheres are closely interrelated since they all deal with affecting other people's emotions and state of mind against their will, we have decided not to take charms for sowing hate and impotence ${ }^{13}$ into consideration. Instead, we focus on charms that are intended to instill love of different sorts. ${ }^{14}$

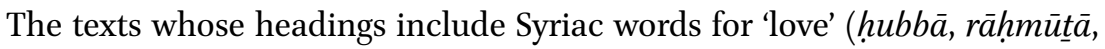
rehmt ța or raḥmē) are found in almost every codex available to us. All these texts can be divided into two major groups, which denote as "the recipe-type" and "the prayer-type". In this paper, which is the first part of our inquiry on Syriac love charms, we analyze the charms of the recipe-type, while the second group will be studied separately in a forthcoming paper. Unlike the prayertype texts, Syriac charms of the recipe-type are very rare. Therefore, we have decided to cover this group in its entirety, including two charms (Text 4 and 5), cited by Badger in his book, ${ }^{15}$ for which we do not have Syriac text. ${ }^{16}$

\section{Special Traits of the Recipe-Type Texts}

As already stated, this group of Syriac love charms encompasses 6 texts, since this equals the number of the charms of this type found in the available

12 Ortal-Paz Saar, Jewish Love Magic, p. 4.

13 We intend to study some unique examples of this very scarcely attested type of Syriac charms in one of the forthcoming papers.

14 In this decision we follow Faraone: "For our purposes, "love magic" will refer almost exclusively to a large body of traditional ritual techniques used by the Greeks to instill or maintain various forms of desire and affection" (Christopher A. Faraone, Ancient Greek Love Magic, Cambridge, 2009, p. 18). On applying these Greek terms to Jewish charms for love and grace see Ortal-Paz Saar, Jewish Love Magic, pp. $2-5$.

15 George Percy Badger, The Nestorians and Their Rituals: With the Narrative of a Mission to Mesopotamia and Coodistan in 1842-1844, Vol. 1, London, 1852, p. 238.

16 On this as well as other manuscripts used in this paper see Appendix. 
manuscripts. Before adducing the charms themselves we will outline the special features of the recipe-type texts. ${ }^{17}$

Regarding their substance and composition, we must admit that all traits common to the entire group deal with the absence of certain features. They are:

- no allusions to the Bible

- no Biblical parallels

- no mentions of any of the hypostases of the Trinity, or Christian saints, etc. In other words, these texts lack most of clear references to their circulation in the Christian milieu which are easy to detect in the rest of Syriac charms. A few exceptions need to be outlined here. Hosts are used as materia magica in Text 1, while Text 3 instructs the practitioner to recite Psalm 46. However, when compared to the prayer-type texts, this feature is still very prominent.

It is much more challenging, however, to find common features which are shared by all the texts of this group and have nothing to do with the absence of something. The table adduced below represents an attempt to outline such features, none of which is common to all the texts, but regarded cumulatively, as we believe, they still represent a significant piece of evidence, since no text matches less than 2 of 4 positions.

Thus, many of the recipe-type charms contain an instruction to perform a kind of magic ritual or, what we call, an allusion to such (cf. Commentaries to Texts 2 and 5 ). These instructions can imply manipulations with certain objects and substances, and we have put such cases in a separate column, named materia magica, or they can prescribe adjuration to some powers, not common to magic texts of Syriac Christians, i.e. not to Christian God, saints, etc. What can be slightly perplexing is that this kind of adjuration more often appears in these charms not as a part of a ritual prescription, but by itself: cf. e.g. "collect dust from the grave-yard and invoke the sun" vs. "I adjure you, holy letters". In the first case the adjuration is part of a prescription to perform a certain ritual, while in the second case it is not. In the column named "adjuration" we include cases of both types. The last prominent feature is the presence of voces magicae in 4 texts out of 6.

The commentaries to the following texts are designed to establish the wider context of the magic formulae and magic practices as attested in these charms, by adducing parallels from outer sources, such as Aramaic magic texts from Late Antiquity (magic bowls and scrolls from the 6th-8th cent. CE), texts from Cairo Geniza (10th-19th cent. CE), Greek and Demotic magical papyri

17 On the few commonalities between the two type of Syriac love charms see Syriac Love Charms. Part II. The prayer-type, forthcoming. 
TABLE 1 Attestation of the special features of the recipe-type in individual texts

\begin{tabular}{lllll}
\hline & voces magicae & materia magica & adjuration & magic ritual \\
\hline Text 1 & + & + & & + \\
Text 2 & + & & + & $+(?)$ \\
Text 3 & & + & & + \\
Text 4 & + & & + & $+(?)$ \\
Text 5 & & + & + & + \\
Text 6 & + & & + & + \\
\hline
\end{tabular}

(abbreviated PGM and PDM respectively, 2th-5th cent. CE) and Coptic magic spells (1th-12th cent. CE).

\section{$3 \quad$ Texts and Commentaries}

3.1 Text 1. For Love (Kazan $4, f \cdot 47 r-47 v)$

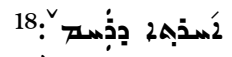

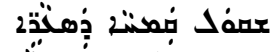

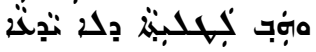

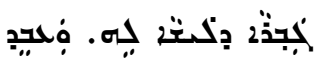

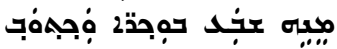

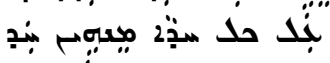

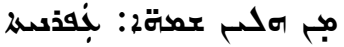

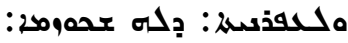

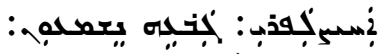

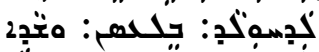

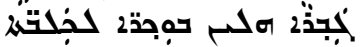

Another [charm]: for love.

Take some barley flour

and give it to a girl who has never known

a man, so that she kneads it. Make

seven hosts of it and write

on each of them one of

these names: 'prnyt?,

l'prnyt', dlh škwzm?,

'hyșlpry, gb'h nšmwn,

$l d h w l d, b l^{\varsigma} s n$, - so that a man

throws these hosts to bitches.

\subsection{1}

\section{Commentary}

This text was put first as it represents most of the features of its type: manipulations with materia magica, voces magicae, brevity and the total absence of

\footnotetext{
18 An abbreviation sign is used. The standard vocalization for this word is rāhmū $\underline{t} \bar{a}$. Here we have rahm- instead.
} 
literary formulae common to the texts of the second type, since Text 1 contains no incantation.

The aim of this recipe, as can be deduced from its content, is to instill love in a woman's heart through certain manipulations with flour, dough and hosts, which also involve the assistance of a virgin and female dogs.

Various parallels to this text can be found in erotic charms belonging to different magic traditions of the Near East, and in the following commentary we outline a few such similarities. Speaking about using flour as materia magica, the first parallel known to us comes from a tablet dated to the 7 th century BCE which contains a Sumerian love incantation accompanied by the description of two rituals in Akkadian..$^{19}$ One of the rituals prescribes the use of flour, which is normally used in offerings: ${ }^{20}$ it should be thrown into a river as a sacrifice to the god Ea. Later in this commentary we address this text more closely.

A few other parallels to our text come from Jewish sources, where flour is used in different magic recipes dealing with love, such as the following text from Sefer ha-Razim: ${ }^{21}$

Take a white cock and fine flour, and slaughter the cock into living water. And with the blood and the water knead the flour and make 3 cakes and place them in the sun, and write upon them in blood the name of the fifth encampment and the name of the overseer. ${ }^{22}$

In addition to using flour, this recipe proceeds with a prescription to knead the dough, bake (or, better to say, dry) a few cakes and inscribe some efficient names on it. All this provides a particularly striking parallel to our text.

Using hosts in a magic ritual is what one may denote as the "Christian layer" in our text. Notably, no other precedents of magic rituals involving the Christian ceremonial items in Syriac charms are known to us.

19 See Robert D. Biggs, ŠÀ.ZI.GA. Ancient Mesopotamia Potency Incantations, New York, 1967, pp. 70-74 (KAR 61). On this text see also Markham J. Geller, "Mesopotamian Love Magic: Discourse or Intercourse?", in: Sex and Gender in the Ancient Near East, Proceedings of the 47th Rencontre Assyriologique Internationale, Helsinki, July 2-6, 2001, ed. Simo Parpola and Robert M. Whiting, Helsinki, 2002, pp. 131-132.

20 Markham J. Geller, Mesopotamian Love Magic: Discourse or Intercourse? In Sex and Gender in the Ancient Near East, p. 132.

21 For the most recent brief account on this late-antique magic compilation see Ortal-Paz Saar, Jewish Love Magic, pp. 22-23. On two more Jewish recipes that require using flour and stem from Cairo Genizah see ibid., pp. 82, 138 .

22 Sefer ha-Razim, First Firmament, lines 161-163. Translation from Ortal-Paz Saar, Jewish Love Magic, p. 129. 
Feeding hosts to a female dog implies likening them to the woman who is the target of the charm, thus providing an example of what Frazer called sympathetic magic. Animals are often mentioned in love charms originating from the Near East and Egypt. Among such cases that which precisely mention dogs are very prominent. For example, a dog features in an Old Babylonian tablet from Isin which contains several Akkadian love incantations:

The dog is lying, the boar is lying -

you lie forever between my thighs. ${ }^{23}$

Here an analogy is implied between the behavior of sexually aroused human beings and that of dogs and pigs. ${ }^{24}$

One of the Coptic erotic spells contains a similar dog analogy: ${ }^{25}$

I desire that N. daughter of N. spend forty days and forty nights hanging on me like a bitch for a dog, like a sow for a boar ${ }^{26}$

According to Saar, ${ }^{27}$ in medieval Jewish magic dogs (as also pigs) are mentioned mainly in incantations for sowing hate, ${ }^{28}$ however it appears reasonable to compare our recipe with one yet unpublished medieval Jewish magic text she adduces:

Write on gazelle parchment and touch the woman and she will follow you. And if you wish to try it put it on the head of a dog and it will follow you. And they are these. $\langle\text { magical signs }\rangle^{29}$

23 Zeitschrift für Assyriologie und Vorderasiatische Archäologie, 75/2 (1985), 198-204, ll. 21-24. Translation is cited after Nathan Wasserman, Akkadian Love Literature of the Third and Second Millennium BCE, Wiesbaden, 2016, p. 258.

24 See also Robert D. Biggs, ŠÀ.ZI.GA, p. 33 (14:9-10).

25 On the popularity of animal analogies in Coptic and Egyptian erotic spells see Marvin W. Meyer and ýRichard Smith, Ancient Christian Magic: Coptic Texts of Ritual Power, San Francisco, 1994, p. 149 .

26 Ibid., p. 153, Text 72:32-36. Another Coptic spell likens the woman whose feelings are intended to be affected to a dog "crazy for its pups" (ibid., p. 159, Text 74:14).

27 Ortal-Paz Saar, Jewish Love Magic, pp. 36-37.

28 Ibid., pp. 126, 136.

29 Jewish Theological Seminary Library 8114, f. 93(94)a: 20-23. Translation cited according to Ortal-Paz Saar, Jewish Love Magic, p. 97. 
We render the magic names that are required to be inscribed on the hosts merely with consonants, but thanks to vocalization dots provided by the scribe

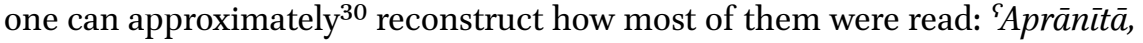

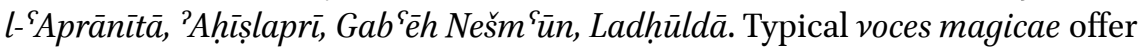
no possibility to interpret them on the basis of the vocabulary of the language in which the other parts of the text are written. This is not completely true for our text or the following ones, as for a few of the names, we can propose a more or less solid interpretation.

The name 'A $\bar{p} r a \bar{n} i \bar{t} \bar{a}$ can be translated as 'earthyf.' Though not in the feminine form, the adjective is well attested in Syriac, e.g. in 1Cor. 15:47 Adam is called 'the first earthy man', i.e. 'made of earth'. Some considerations let us suppose that this name was not used in this text accidentally or randomly. The magic practices intended to instill love may include manipulations with clay. ${ }^{31}$ We often find prescriptions either to make a figurine, representing the target of the spell, ${ }^{32}$ and sometimes to also inscribe the target's name on it, or to inscribe something on a piece of unbaked clay or on a sherd. In some cases, clay products of both types are to be burnt, performing a sympathetic magic ritual: the target of the spell is supposed to burn with passion as the figurine or the piece of clay burns in the fire. ${ }^{33}$ Instead of burning, the Akkadian ritual that follows the Sumerian love incantation in KAR 61, mentioned above in connection with using flour as materia magica, prescribes burying the figurine in the place where the target is supposed to pass, implying a contagious magical effect: ${ }^{34}$

30 We say "approximately" because the scribe has not provided diacritics that would point to spirantized/unspirantized pronunciation of $b g d k p t$.

31 See Ortal-Paz Saar, Jewish Love Magic, pp. 119-120 on the explicit and implicit analogies of the ritual and its wide attestation in various magical traditions of the Near East.

32 On this practice see Robert D. Biggs, Š̀̆.ZI.GA, pp. 70-71, Ortal-Paz Saar, Jewish Love Magic, pp. 146-147.

33 On a Jewish love charm written on burnt clay sherds see commentary to Text 5 . See also Robert D. Biggs, Š̀̀.ZI.GA, p. 28 (11:22-24), where a prescription to prepare two figurines of clay and other materials and burn them afterwards is found.

Another attestation of this practice in Mesopotamian erotic magic is KAR 69:26 (Robert D. Biggs, Š̀̀.ZI.GA, p. $7^{-76}$ ). For the most recent and detailed survey on the practice of using figurines and other representations of the spell target in the magic of the Near East, Greece and Egypt see Andrew T. Wilburn, "Figurines, Images, and Representations Used in Ritual Practices", in: Guide to the Study of Ancient Magic, Leiden, 2019, pp. 456-506. On using clay sherds and figurines with malicious purposes in Egypt cf. Mirecki-Meyer 2002:433-434, in Mesopotamia cf. Daniel Schwemer, "Mesopotamia", in: Guide to the Study of Ancient Magic, Leiden, 2019, pp. 44-46. 
If that woman (still) does not come, take tappinnu

flour

(and) throw (it) into the river to king Ea;

You take clay from(?) both river (banks),

From the far side (of the Tigris) and the far side (of the

Euphrates);

You make a figurine of that woman, you write her name on its left hip;

Facing Shamash you recite the incantation 'The beautiful woman'

[Over] it. At the outer gate

Of the West Gate you bury it.

During the hot part of the day(?) or during the evening(?) she will walk over it.

The incantation 'The beautiful woman' you recite three times;

That woman will come to you (and) you can make love to her. ${ }^{35}$

In other words, the presence of the name ${ }^{\varsigma} A \bar{p} r a \bar{n}$ it $\underline{t} \bar{a}$ in our text may refer to this widespread magical practice, though it is not explicitly mentioned in this text. Notably, we find the Syriac word for 'clay' among voces magicae in Text $6 .{ }^{36}$

Another name, that can at least partly be interpreted within Syriac vocabulary, is Gab ${ }^{\varsigma} \bar{e} h$ Nešm ${ }^{\varsigma} \bar{u} n$, where nešm ${ }^{\varsigma} \bar{u} n$ represents a finite verbal form (impf. 3 m. pl.) from šma 'to hear, listen, ${ }^{\text {' }}{ }^{7}$ and thus can be translated as 'let them hear' or 'they will hear'.

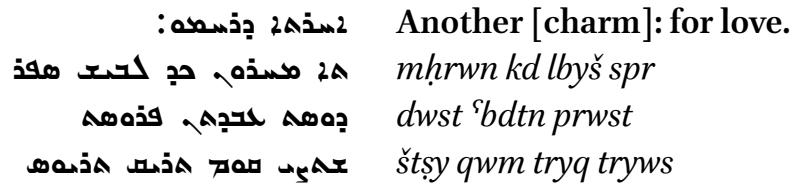

35 KAR 61:11-21. Translation from Robert D. Biggs, ŠÀ.ZI.GA, p. 7 O.

36 According to Wasserman(Nathan Wasserman, "Old-Babylonian, Middle-Babylonian, NeoBabylonian, Jewish-Babylonian?: Thoughts about transmission modes of Mesopotamian magic through the ages," in: Encounters by the Rivers of Babylon, ed. Uri Gabbay and Shai Secunda, Tübingen, 2014, p. 265) "the Aramaic rituals [involving unbaked clay] lean here on ancient Mesopotamian practice".

37 Michael Sokoloff, A Syriac Lexicon: A Translation from the Latin: Correction, Expansion, and Update of C. Brockelmann's Lexicon Syriacum, Winona Lake, 2009, p. 1574. 


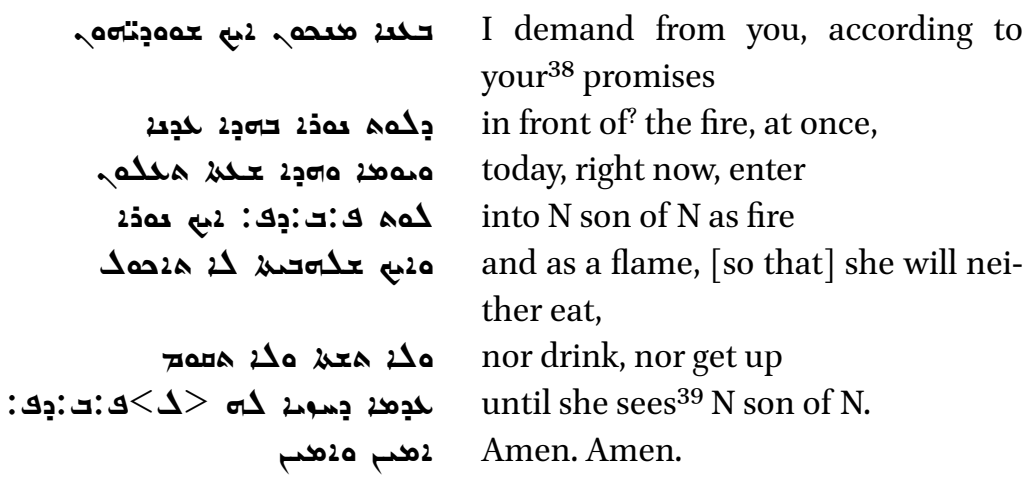

كل2 I demand from you, according to your ${ }^{38}$ promises

in front of? the fire, at once, today, right now, enter into $\mathrm{N}$ son of $\mathrm{N}$ as fire and as a flame, [so that] she will neinor drink, nor get up Amen. Amen.

\subsubsection{Commentary}

This text is intended to induce love in a woman's heart. It starts with voces magicae. As in Text 1 , this is not a typical example of abracadabra since most of the words seem to be of clear Syriac (or at least Aramaic) origin, however, they do not make any sense when analyzed as a sentence (or a group of sentences). Given that among the most clearly identifiable words are kad 'when, while',

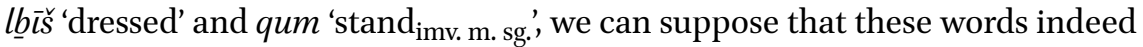
could represent a corrupted Syriac text.

The charm proceeds with adjuration: $b \bar{a}$ ' $\bar{e} n \bar{a}$ 'I demand from you pl.masc.'. This clearly indicates that as in Text 1 these voces magicae (or some of them) act here as names of some supernatural powers (cf. Text 4). However, the following text is evidently corrupted. Presumably, these voces magicae are invoked and, assuming a textual mistake (suff. 2 pl.m. instead of 3 m.pl.), asked to fulfill their promises. It is difficult to establish on which of the preceding words Syr. da-lwāt nūra 'in front of (or near) the fire' is syntactically dependent. The phrase seems to be a reminiscent of some fire ritual, similar to the ones that we mentioned in connection with Text 1 . Indeed, a ritual prescription is present (or alluded to) in most of the texts of this type ${ }^{40}$ and, providing that words da-lwāt nürā are difficult to interpret within the present textual context, an assumption can be made that at least at some earlier stage of the text tradition this incantation was accompanied by a magical procedure. The Syriac words

38 Translation is based on reading

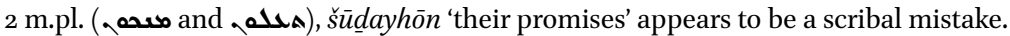

39 Any interpretation of this passage implies a scribal mistake. Our reading $d$-hāazyā lēh 'until she sees him' supposes that the scribe omitted $l$ - after lēh, i.e. : ده: possible interpretation is $d$-hazyā lēh 'until he sees her' (or, literally, '(until) she is seen by him'), which still requires the same emendation of the text as the preferred interpretation does.

The only unambiguous exception is Text 4 . 
meaning 'stand', 'dressed' and 'while' found among the voces magicae increase the plausibility of this interpretation. Finally, this text, corrupted as it is, still represents a clear parallel to Text 5 , where an allusion to a fire ritual can also be assumed (cf. commentary to Text 5 ).

A lot of recipes intended to instill love and displaying similar structure can be found among the Geniza texts, of which we adduce one example:

For a man to be liked and loved by everyone who looks at him. Write, and suspend from the left arm: (magic characters). You, holy letters and [praised] characters. Give grace, charm and love to N. son of N. in the eyes of every one who looks at him and who hears his voice ${ }^{41}$

The following formula "Enter into NN as fire ..., so that she neither eats, nor drinks ..." appears to be a combination of the two most common formulae in love magic. Both of these formulae represent the motif of love as a torment or a disease and intend to inflict the spell target with the same sufferings that are being experienced by the client himself. ${ }^{42}$

The first formula in question deals with love or sexual desire affecting its subject as fire (LOVE IS FIRE ${ }^{43}$ ). It is extremely popular in erotic magic and widely represented in texts originating from the Near East, Egypt and Greece, starting from Greek magical papyri (PGM), after which, retaining its popularity in the Coptic spells, it can still be found in medieval Jewish and Islamic magic. ${ }^{44}$

41 Translation cited after Joseph Naveh and Shaul Shaked, Magic Spells and Formulae: Aramaic Incantations of Late Antiquity, Jerusalem, 1993, pp. 195-196 (Geniza 18, 17:1318:3). See also ibid., p. 192 (Geniza 9).

42 See John J. Winkler, "The constraints of Eros", in: Magika Hiera: Ancient Greek Magic and Religion, eds. Christopher A. Faraone and Dirk Obbink, New York, 1991, pp. 216, 230-233; Eleni Pachoumi, "Eros as disease, torture and punishment in magical literature", Symbolae Osloenses, 86/1 (2012), pp. 74-93. At the first glance this intention to hurt your beloved one may seem paradoxical. However, as rightfully outlined by Eleni Pachoumi, "the erosdisease symptoms, or tortures were temporary, only until the two entities of this sexual discourse (: user and victim of the erotic spell) meet and the goal of the spell is fulfilled" (Eleni Pachoumi, "Eros as disease, torture and punishment in magical literature", p. 85).

43 With small capital letters we mark conceptual metaphors. Hereby we follow Saar (OrtalPaz Saar "Fire Symbolism in Late-Antique and Medieval Jewish Love Magic", Groniek, 220 (2019), pp. 315-316), who applies the term "conceptual metaphor" used in cognitive linguistics to the most common motifs of Jewish love magic. Thus, under the expressions of the metaphor LOVE IS FIRE, studied by Saar in the first place, we can unite not only different formulae, occurring in love charms, but also magic practices which deal with burning (see commentary to Text 1 ).

44 On the underlying metaphor see Ortal-Paz Saar, Jewish Love Magic, p. 119. Cf. also commentary to Text 5 . 
This said, it is not unexpected that this motif is expressed not once in our small corpus: cf. Text 5 .

The second formula is about the target's inability to eat and drink (and often sleep) before he/she sees or comes to the client (LOVE IS ABSTINENCE ${ }^{45}$ ). As shown by Martinez, the formula and the motif which stands behind this has deep roots in Greek and Jewish literature and magic tradition. ${ }^{46}$ However, the earliest reminiscent of this motif known to us comes from an Akkadian incantation:

Be (f.) awake at night-time!

At day-time may you(f.) not sleep!

At night-time may you(f.) not sit down!

Incantation of the lover. ${ }^{47}$

Below we cite an elaborate one Coptic incantation which contains both motifs and also illustrates the thesis that the spell beneficiary aims to induce in the target the same feelings by which he himself is afflicted. It is the spell of Cyprian of Antioch, which begins with a description of the hero (Cyprian, but we can argue with enough probability that it also relates to the client) suffering from love:

I am all afire. I have lain down to rest, but I could not sleep; ... I have eaten and drunk in sighing and groaning 48

The text proceeds with an adjuration to God:

He comes in the rush of his power at your command, $\mathrm{O}$ father of the aeons, to go to N. daughter of N.... filling her heart, her soul, her spirit, and her mind with burning desire and hot longing.... She must not eat or

45 The same conceptual metaphor clearly underlies a following formula from the Old Akkadian incantation MAD v.8 (ll. 33-38), dated to the 2200 BC: "So long as his neck and your neck are not entwined / May you not find peace!", see Joan and Aage Westenholz, "Help for rejected suitors. The Old Akkadian love incantation MAD V 8", Orientalia, 46 (1977), p. 203, see also Ortal-Paz Saar, Jewish Love Magic, p. 34 on the commonness of the motif.

46 David Martinez, "'May She Neither Eat nor Drink ...': Love Magic and Vows of Abstinence," in: Ancient Magic and Ritual Power, ed. Paul Mirecki and Marvin Meyer (Religions in the Graeco-Roman World, 129), Leiden, 1995, pp. 335-359.

47 Zeitschrift für Assyriologie und Vorderasiatische Archäologie, 75/2 (1985), 200-201. Translation cited according to Nathan Wasserman, Akkadian Love Literature, p. 261.

48 Marvin W. Meyer and Richard Smith, Ancient Christian Magic, p. 154, Text 73, p. 1, ll. 6-11. 
drink, slumber or sleep, for her garments burn her body, the sky's lightning sets her afire, and the earth beneath her feet is ablaze ${ }^{49}$

Both formulae occur in other Syriac love charms. The motif of burning is also found in Text 5 .

$$
\begin{aligned}
& \text { Text 3. For Love: For a Woman So That Her Husband Would Love Her } \\
& \left(H_{16} \text { o,ff. } 44 v-45 r\right)
\end{aligned}
$$

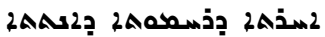

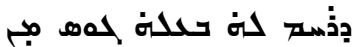

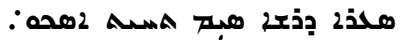

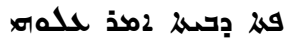

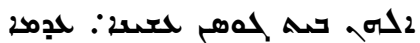

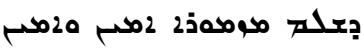

Another [charm] for love:for a woman

so that her husband would love her. Cut off?50 some

hair from [her?] head, put [it] under the house's

threshold. Recite over it:

"God is our refuge and strength" 51 till the end of the psalm. Amen. Amen.

\subsubsection{Commentary}

The charm is designed to induce or reinforce love in one of the spouses. Two interpretations for the heading are possible, depending on our translation of d-rāhem lāh ba lāh: 'so that her husband would love her' or 'whose husband loves her'. Preferring the first interpretation, we suppose, that the woman is a client, seeking her husband's love, while in the second case it would be the other way around. The text prescribes using hair, which probably belongs either to the client or to his wife, and to put it under the house's threshold. Finally, Psalm 46 is to be recited.

Using hair in a magic ritual is what we call contagious magic, following Frazer's terminology. This well-known magic practice can be performed with different purposes besides instilling love, e.g. to curse, to cure, or to exorcise evil spirits. ${ }^{52}$

49 Ibid., p. 155, Text 73, p. 5, ll. 85-103.

50 This word can be understood as an imperative from the verb gss 'to recline, to place', though the last is attested in Aphel only (Michael Sokoloff, A Syriac Lexicon, p. 251). However, as suggested by Matthew Morgenstern in a personal conversation, the form $g w s$ here can be interpreted as related to the root $g z z$, cf. $g z z$ Pe. 'to shear' (Michael Sokoloff, $A$ Syriac Lexicon, p. 224). The unusual form solgos in this text may be explained either by the graphic resemblance to _rom Ps 46:2: 'alähä bèt gawsan 'God is our refuge' which is quoted three lines after, or as derived from a root variant of $g z z$ 'to shear', i.e. otherwise unattested verb gss.

$51 \quad$ Ps $46: 2$.

$5^{2} \quad$ For cursing see Marvin W. Meyer and Richard Smith, Ancient Christian Magic, p. 203 (Text 96:31); for healing see ibid., p. 88 (Text 43:10:163); for exorcising see Jo Ann Scurlock, 
In our text the use of hair belonging either to the spell beneficiary or to the spell target is intended to strengthen the bond between these two persons. ${ }^{53}$ The contagious effect is increased by putting the hair under the threshold, where the target is supposed to pass. ${ }^{54}$

A few parallels can be found in the texts stemming from another branch of Christian magic - the Coptic spells. Below we adduce two erotic spells that also require putting the produced spell at the target's door.

Write these signs on a sheet of tin.... Bury it at the woman's door ${ }^{55}$

I adjure you by your powers and your amulets and the places where you dwell and your names, that just as I take you and put you at the door and the pathway of Phello son of Maure, (so also) you must take his heart and his mind; you must dominate his entire body ${ }^{56}$

While recitations and written quotations of Psalms is a very well documented practice in Jewish and Christian magic, ${ }^{57}$ to our knowledge, Psalm 46 is not mentioned or cited in any other magic text of either of the two traditions.

\subsection{Text 4. Charm to Excite Love in a Woman towards a Man (Badger I:240)}

In the name of the talismans, Hazo, Tof, Misceteeso, Mar Dileetos, Partos Isteepis, Mar Yesus, Diotaros, and Maximus, go presently and hastily to A.B. the daughter of C.B. and deprive her of her mind and understanding,

"Magical Uses of Ancient Mesopotamian Festivals of the Dead" in: Ancient Magic and Ritual Power, eds. Paul Mirecki and Marvin Meyer, Leiden, 1995, p. 97.

53 See Ortal-Paz Saar, Jewish Love Magic, pp. 134-143 on manipulations with hair, nailclippings and other materia magica taken from the human body in Jewish love magic. Examples from PDM include PDM xiv. 1063-69, PDM xiv. 1070-77 (Hans Dieter Betz (ed.), The Greek Magical Papyri, Vol I, Chicago, 1986, p. 246). Discussing magic practices attested in Greek magical papyri (PGM), Winkler claims that "all prescription love spells were actually found wrapped with hair" (John J. Winkler, "The Constraints of Desire. The Anthropology of Sex and Gender in Ancient Greece", in: Magika Hiera: Ancient Greek Magic and Religion, eds. Christopher A. Faraone and Dirk Obbink., New York, 1991, p. 224). See also Andrew T. Wilburn, "Figurines, Images, and Representations Used in Ritual Practices", pp. 46o-463.

54 On this see ibid., p. 598.

55 Marvin W. Meyer, Richard Smith, Ancient Christian Magic, p. 159 (Text 74:2-4).

$56 \quad$ Ibid., p. 177 (Text 84:4-8).

57 On using biblical quotations from different books of the Bible in Jewish love magic see Ortal-Paz Saar, Jewish Love Magic, pp. 188-191, on using book of Psalms in particular see Gideon Bohak, Ancient Jewish Magic: A History, Cambridge, 2008, pp. 406-407. 
that she may run after M.D. the son of N.D. I demand of these names that A.B. may also go after M.D. and follow him from house to house, from town to town, from village to village, from city to city, and from market to market. Even so order it to be. Amen and Amen.

\subsubsection{Commentary}

For Texts 4 and 5 we have only English translation (see Appendix).

At the beginning of the charm the "names of the talismans" are adduced, which are used (cf. Text 2) to immediately affect the mind of a certain woman, so that she starts seeking the spell beneficiary in a wide range of locations.

Below we elaborate upon two common motifs attested in this charm.

One of them depicts love and passion as depriving their subject of mind and consciousness (LOVE IS MADNESS). One parallel comes from the Coptic erotic spells:

I adjure you by all these things for the sake of a heartfelt love and a pang and a heartfelt madness in the heart of N. daughter of N. Quickly!58

Having lost its mind, the target has to submit to the will of the spell beneficiary, contrary to his/her own will. This is what Saar includes in her list of "preliminary goals" of love spells. ${ }^{59}$

An intention to get control over the spell target not only via his/her heart, but also through subjugating his/her mind, soul, (parts of) body, etc. is most notably expressed in Greek and Demotic magical papyri (PGM and PDM) and defixiones, from where it was presumably inherited by the Coptic erotic spells. ${ }^{60}$

You must take his heart and his mind; you must dominate his entire body ${ }^{61}$

$5^{8}$ Marvin W. Meyer, Richard Smith, Ancient Christian Magic, p. 159 (Text 74:9-10).

59 "The target should ignore his/her own wishes, abandon any family ties, and focus only on the spell beneficiary. The free will and/or the body of the target are bound through magical means, so that they are no longer autonomous", see Ortal-Paz Saar, Jewish Love Magic, p. 57 .

6o Marvin W. Meyer, Richard Smith, Ancient Christian Magic, p. 148.

$61 \quad$ Ibid., p. 177 (Text 84:7-8). Cf. also Text 73 ("Erotic spell of Cyprian of Antioch"): "go to N. daughter of N.... filling her heart, her soul, her spirit, and her mind with burning desire and hot longing, with perturbation and disturbance, filling her from the toenails of her feet to the hair of her head with desire and longing and lust, as her mind is distracted, her senses go numb, and her ears are ringing", ibid., p. 155 (Text 73, p. 4, ll. 86-99). In PGM this motif is attested e.g. in PGM CIX. 1-8, see Hans Dieter Betz (ed.), The Greek Magical Papyri, Vol I, p. 221. 
The second motif deals with inducing an uncontrollable urge in the spell target to run or search for the spell beneficiary. We find this motif already in a Sumerian love incantation, ${ }^{62}$ but in PDM it is attested within more elaborate formulae:

The love which Isis felt for Osiris, when she was seeking after him everywhere, let NN, the daughter of $\mathrm{NN}$, feel it, while seeking after $\mathrm{NN}$, the son of NN, everywhere ${ }^{63}$

Let her feel a yearning, a love, a great madness..., she seeking after him everywhere ${ }^{64}$

The closest parallel known to us, however, once again is attested in Coptic erotic spells:

He must seek me from town to town, from city to city, from field to field, from region to region, until he comes to me and subjects himself under my feet ${ }^{65}$

Words "go presently and hastily" addressed to the talismans in our text, provide an inner parallel within our small corpus, reminding us of the similar urging ("at once, today, right now") contained in Text 2. Though in both cases it is the adjured powers who are asked to hurry, we can still consider them in relation to another preliminary goal of love spells, listed by Saar: "The target should promptly yearn for contact with the spell beneficiary, promptly and immediately".66 Both goals - to hasten the powers to operate and to hasten the spell target to come to the spell beneficiary - indicate the clients' impatience to see the charm working. We find many examples of this in PGM,

62 Cf. a Sumerian incantation for love sickness (rev. l. 33), which says: "May she run after me!" (Markham J. Geller, “Mesopotamian Love Magic: Discourse or Intercourse?”, p. 137). On this motif in ancient Semitic literature see Joan and Aage Westenholz, "Help for rejected suitors. The Old Akkadian love incantation MAD V 8", p. 214.

63 PDM xiv. 459-75. Translation cited after Hans Dieter Betz (ed.), The Greek Magical Papyri, Vol I, p. 221.

64 PDM xiv. 1049-55. Translation cited after ibid, Vol I, p. 221.

65 Marvin W. Meyer and Richard Smith, Ancient Christian Magic, p. 177 (Text 84:10-14). Cf. also "Let her constantly ask after him, every moment, all the time, at every hour, her and his whole life long”, see ibid., p. 157 (Text 73: 204-207).

Ortal-Paz Saar, Jewish Love Magic, p. $5^{8}$. 
where most of the love spells end with the words "immediately, immediately, quickly, quickly". 67

\section{$3 \cdot 5$}

\section{Text 5. Charm to Excite Love in a Man towards a Woman (Badger I:239)}

I ascend seven mountains, and descend into seven valleys, and I saw there a tree of frankincense, and I conjure with awful oaths, that as incense burns in the fire even so may A.B. the son of C.B. [his mother] burn with love of C.D. the daughter of E.D. [her mother.] amen.

\subsubsection{Commentary}

At the beginning the charm mentions a journey undertaken by an unidentified character, which is probably to be associated either with the "magician" (i.e. the person, who performs the ritual) or the spell beneficiary. The goal of his journey, as we can tentatively deduce from the text, is to find the frankincense tree and, probably, to obtain some frankincense. The adjuration which follows has no specified addressee. It contains a formula, that likens the burning of frankincense with the burning of the female target's heart with love. Though the text lacks any clear ritual instructions, we can consider these lines to be an allusion to a burning ritual in view of both the inner and outer comparative data (cf. commentary to Text 1 and 2 and v. below).

Brief as it is, this text contains a few features very prominent in ancient magic and love literature. Such landscapes as gardens and valleys with delicious fruits and beautiful flowers, springs with pure and sweet water, and fertile fields are frequently mentioned in love lyrics and erotic incantations of the Near East and Egypt. ${ }^{68}$ Most scholars agree that, though these places represent symbols of love and pleasure in general, in many cases these passages allude to women's beauty and sexuality or to female genitalia, while descriptions of

67 Hans Dieter Betz (ed.), The Greek Magical Papyri, Vol I, pp. 19, 39, 251, 257, 270, 271, 278, 309 , 312, etc. However, it is worth noting that this formula in PGM is not used exclusively in love spells, being attested also in spells, protecting from fever (e.g. ibid., pp. 281, 302), and a request for a dream oracle (e.g. ibid., p. 123), etc.

68 Such biblical parallels as Cant 6:2, 4:16-5:1, Hos 14:7, et al. are often considered, too, see Joan and Aage Westenholz, "Help for rejected suitors. The Old Akkadian love incantation MAD V 8", pp. 212-213, Shalom M. Paul, "A Lover's Garden of Verse: Literal and Metaphorical Imagery in Ancient Near Eastern Love Poetry," in: Tehillah le-Moshe:Biblical and Judaic Studies in Honour of Moshe Greenberg, ed. Mordechai Cogan et al., Winona Lake, 1997, pp. 105-110. 
characters coming to these places and finding pleasure there are to be interpreted as allusions to sexual intercourse. 69

Of all parallels we adduce one, which comes from the Old Akkadian incantation MAD V. 8 and is of special interest, since it also mentions a journey and obtaining incense as its possible goal:

I am guided by(?) the sapflow of the incense-tree.

Two beautiful maidens were blossoming,

They went down to the garden,

To the garden they went down.

They cut from the sapflow of the incense-tree ${ }^{70}$

In their study of this incantation, J. Goodnick and Aage Westenholz adduce parallel passages from Mesopotamian literature and the Song of Songs, arguing that fragrance serves as a metaphor for attractiveness in love lyrics. ${ }^{71}$

The following lines of our text are particularly significant not only since they contain another attestation of the LOVE IS FIRE metaphor in our corpus (cf. Text 2), but also due to the very formula in which this metaphor is expressed. The most ancient attestation of this formula is found on five pieces of potsherd dated to the $5^{\text {th }}$ or 6 th cent. CE, which were discovered during the excavations of the ancient synagogue in Ḥorvat Rimmon:

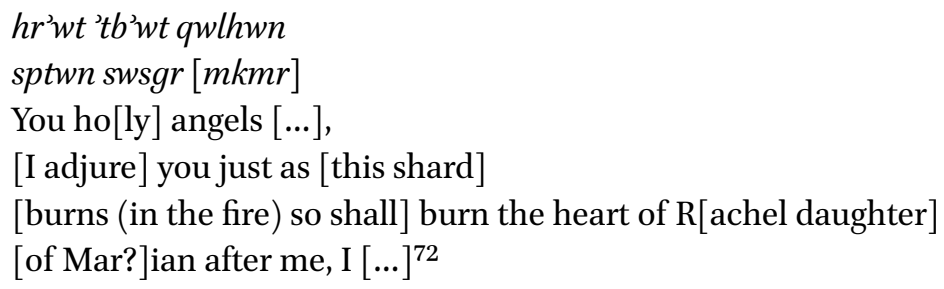

69 See ibid., p. 10o; Joan and Aage Westenholz, "Help for rejected suitors. The Old Akkadian love incantation MAD V 8", pp. 212-214, Nathan Wasserman, Akkadian Love Literature, pp. $32,37,43$.

70 MAD v.8, ll. 5-10. Cited according to Benjamin Read Foster, Before the Muses: An Anthology of Akkadian Literature, Bethesda, 2005, p. 66.

71 Joan and Aage Westenholz, "Help for rejected suitors. The Old Akkadian love incantation MAD V 8", pp. 215-216.

72 Cited according to Ortal-Paz Saar, Jewish Love Magic, p. 118. For an earlier edition see Joseph Naveh and Shaul Shaked, Amulets and magic bowls: Aramaic incantations of late antiquity, Jerusalem, 1985. pp. 86-87. See also Nathan Wasserman, "Old-Babylonian, Middle-Babylonian, Neo-Babylonian, Jewish-Babylonian?: Thoughts about transmission modes of Mesopotamian magic through the ages," pp. 264-265. 
The Aramaic text of the incantation is reconstructed according to a few similar recipes, found among Geniza magic books, ${ }^{73}$ which prescribe writing these voces magicae on a piece of unbaked clay and throwing it into the fire. Originating most probably in Jewish magic, this formula went far beyond Geniza recipe books, extending to other magical traditions ${ }^{74}$ and, eventually, to the Syriac Christian charms.

\subsection{Text 6. For Love of Everyone $\left(H_{1} 62, f . w\right)$}

\begin{tabular}{|c|c|}
\hline 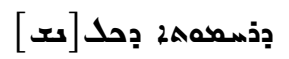 & For love of everyone. \\
\hline 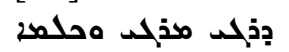 & drgy mrgy and $k \mathrm{~lm}^{?}$ \\
\hline حذ حلهم2 حذ & son of $b^{5} w m^{2}$ son of \\
\hline 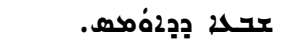 & seven $d d^{2} w m s^{75}$ \\
\hline لبعد مجكها & clay and špyțn? \\
\hline لحمد 20000 & ${ }^{s} m y^{76} s w s w^{777}$ \\
\hline ل & 'ryws and 'py- \\
\hline 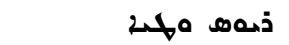 & ryws and ty? \\
\hline مهذد عمع2 & and invoke the sun \\
\hline & and the moon. These [names] \\
\hline هor لمر هبم & be? with the one who \\
\hline مa & bears these writs \\
\hline 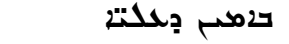 & as guaranteed by the heavenly beings \\
\hline 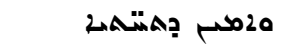 & and guaranteed by the mortals. ${ }^{78}$ \\
\hline & Amen. \\
\hline
\end{tabular}

73 See, e.g., Joseph Naveh, Shaul Shaked, Magic Spells and Formulae, pp. 216-219 (Geniza 22 1:8-16).

74 On other attestations of the formula in Jewish magic see Gideon Bohak, Ancient Jewish Magic, pp. 156-157, Ortal-Paz Saar, Jewish Love Magic, p. 119, on attestations in other traditions see ibid., p. 47 (in Greek magic), pp. 55-56 (in Islamic magic).

75 As proposed by Matthew Morgenstern in a personal conversation, the word may be

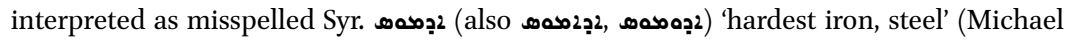
Sokoloff, A Syriac Lexicon, p. 10).

76 The verb $\varsigma_{s ̌ m}(\mathrm{a} / \mathrm{o})$ in Pe. means 'to force, to oppress' (Michael Sokoloff, $A$ Syriac Lexicon, p. 1145).

77 The verbal root swsy means 'to heal, to care' (ibid., p. 986).

78 Translated according to a similar expression בحمم dered in Thesaurus Syriacus as "cum consensu et rerum caelestium et terrenarum" (TS

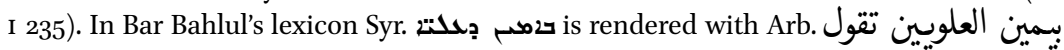
'with an oath of the heavenly beings (or 'angels'). [i.e.] The heavenly beings say: "Amen"' (Rubens Duval, Lexicon Syriacum auctore Hassano bar Bahlule, Vol. 1, Paris, 1901, p. 185b). 


\subsubsection{Commentary}

Nothing but the heading unequivocally points to this text being relevant for our inquiry. The heading itself can be interpreted in two different ways: either the charm aims to instill love towards the spell beneficiary in a person of any sex or it is intended to help its beneficiary to find grace in every person he/she meets.

Starting with a set of voces magicae, among which we find recognizable Syriac words 'seven', 'son', and 'clay', ${ }^{79}$ the text proceeds with a requirement to invoke the sun and the moon. As far as the structure of the text is concerned, Text 6 resembles Texts 2 and 4: all three charms begin with voces magicae and proceed with magic formulae. However, among these two, Text 4 represents a closer comparison to our charm, since it also contains an allusion to a magical procedure in between these two blocks.

Invocations to the sun and the moon can be found among love spells belonging to Greek $^{80}$ and Jewish ${ }^{81}$ magic, but in each case, they do not seem typical for love charms. ${ }^{82}$

There are two more Syriac charms that contain a similar set of voces magicae. Both texts were published by Gollancz. The first of them ${ }^{83}$ is headed thlsm da-qdām šulțāne 'An amulet of avail before the rulers' and shows a lot of similarities with our text. This is a very short spell which begins with drgy mrgy and other voces magicae (partly similar to ours), mentions the sun and the moon, and ends with 'Let them be with the bearer of these writs.' The second text ${ }^{84}$ seems to have two headings: 'assārā $d-{ }^{2} a h \underline{i} \underline{d} \bar{e}$ 'Binding of the tyrants' and 'assārā d-leššāne 'Binding of the tongues'. With our charm it shares some of the voces magicae and the mention of the sun and the moon, but at the same time this text contains a few formulae of Christian origin: the trinitary formula and biblical allusions. If we consider all three texts to be textual variants of one charm, these Christian features could represent a problem for our classification of Syriac love charms. As outlined above, commonly we do not find

79 Cf. tentative comparisons between some other voces and Syriac lexemes adduced in the footnotes above.

8o Christopher A Faraone, Ancient Greek Love Magic, pp.139-141.

81 Ortal-Paz Saar, Jewish Love Magic, pp. 227-228, see also Christopher A Faraone, Ancient Greek Love Magic, p. 103.

82 Thus, Faraone (ibid., p. 139) qualifies this tradition as "very poorly documented" in Greek love magic. Regarding Jewish love spells, they often mention the sun and the moon (v. Ortal-Paz Saar, Jewish Love Magic, Index of subjects), however the invocation to these celestial bodies is mentioned only in one of the spells in Saar's book (ibid., pp. 227-228).

83 вм Or. 6673, §55 (Hermann Gollancz, The Book of Protection, p. 97).

84 Cod. C, §11, see Hermann Gollancz, The Book of Protection, p. 83 (Syriac text), p. lxxix (English translation). 
this kind of evidence in the recipe-type texts. However, when compared to the other two variants that lack these features, we can define them as later editorial changes.

The biblical allusions in Cod. C, §11 are of interest not only for the matters of our classification. In this text we find three allusions to the biblical precedents, each introduced by 'aykannā $d$-rāhem 'alāhā 'Same as God loved...': they recall the biblical stories about Moses, David and Daniel. Though we consider these allusions to be later additions, together with the heading of our text they represent a valuable peace of evidence for classifying this text as a love charm.

\section{Appendix}

\section{The Manuscripts}

\section{Introductory Notes}

According to the catalogue descriptions, the manuscripts kept in Houghton library were either acquired from Shedd or were obtained by the library from the collection of Hall, after his death. The study of two manuscripts, $\mathrm{H} 156$ and $\mathrm{H} \mathrm{160}$, has shown that these mss. may come either from the same hand or from the same scribal school. Although they were acquired by the library from different sources $(\mathrm{H} 156$ from Shedd, $\mathrm{H} 16$ o from Hall), it may well be that both collections, the one owned by Shedd and the one owned by Hall, originate from the same lot of manuscripts brought from Urmia by the end of the 19th century. Isaac H. Hall has published a Syriac charm taken from one of the manuscripts in the possession of "Colonel Elliott F. Shepard, of New York City". Our research of one of the mss. kept in the Houghton library has shown that the Syriac text in the publication by Hall is taken from Houghton syr. $163 \mathrm{f}$. 62 . Therefore, at least this manuscript, acquired by the library after the death of I.H. Hall from his collection, originates from the collection of F. Shepard. Further information in Hall's article ("Colonel F. Shepard, of New York City, obtained recently a number of books of charms and incantation, and other like matter, written generally in good Nestorian script") may lead to the assumption that all the three Houghton manuscripts of Syriac charms obtained from Hall's collection (syr. 16o, 161, 163; our H 16o, H 161, H 163) originate from the collection of Elliott F. Shepard (1834-1893).

\section{Badger's Manuscript}

Texts 4 and 5 are taken from the manuscript which was in the possession of George Percy Badger (1815-1888), following his own remark: "I have in my possession an entire volume of these charms, from which the following specimens are translated". ${ }^{5}$

85 G.P. Badger, The Nestorians and Their Rituals: With the Narrative of a Mission to Mesopotamia and Coordistan in 1842-44, Vol. 1, London, 1852, p. 238. 
Unfortunately, the present whereabouts of this ms. is not known. A number of Syriac mss. from the collection of G.P. Badger were acquired by The Cambridge University Library: Adds. 2887-9, 2903. 2919, 3086, 3087. ${ }^{86}$ One of these mss., Add. 3086, is a collection of Syriac charms. It was published by H. Gollancz in 1912 with English translation. ${ }^{87}$ As noted by Wright (with some hesitation) in his catalogue, Add. 3086 is not the manuscript in question. ${ }^{88}$ The edition of $\mathrm{H}$. Gollancz has confirmed the above assumption of W. Wright. The rest of the seven mss. which came to the Cambridge library from the collection of G.P. Badger have nothing to do with magic, according to Wright's catalogue.

\section{$\mathrm{H} 160$}

Houghton Library at Harvard University (Cambridge MA, USA), ms. Syriac 16o. Former owner: I.H. Hall (1837-1896). Title: kțībtā da-nțuryā 'Book of Protection'. Paper, 49 leaves, bound, $12 \times 8 \mathrm{~cm}$. Textual block includes 18 lines. East Syriac (Nestorian) script without vocalization. Part of the text is written diagonally. 74 chapters, 17 illustrations. Date and place: 1804, in the village of Shibāni, Tergawar district (Hakkari, Turkey). Creator: Gewargis bar Zay`a from Shamsdin. Literature: M.H. Goshen-Gottstein, Syriac manuscripts, p. 104. Digital resource: https://hollis.harvard.edu/. According to the order of the chapters, the shape of the illustrations and some other features, manuscripts $\mathrm{H} 160$ and $\mathrm{H}_{15} 6$ probably originate from the same scribal school.

\section{$\mathrm{H} 162$}

Houghton Library at Harvard University (Cambridge MA, USA), ms. Syriac 162.

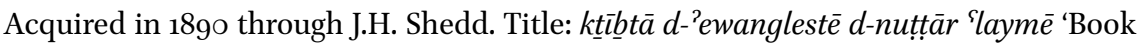
of Evangelists for the Protection of Youths'. Paper, 5 o leaves, bound, $8 \times 5 \mathrm{~cm}$. Textual block includes 14 lines; almost half of the pages are written diagonally or partly diagonally. 45 chapters, 14 illustrations. Not dated. The manuscript is incomplete at the end, because the text of the last chapter breaks off on the last page of the manuscript. Literature: M.H. Goshen-Gottstein, Syriac manuscripts, p. 105. Digital resource: https:// hollis.harvard.edu/.

86 W. Wright, A Catalogue of the Syriac Manuscripts Preserved in the Library of the University of Cambridge, Vol. 1, Cambridge, 19o1, p. xvii.

87 Gollancz H. The Book of Protection, pp. 77-92 (Syriac text), pp. lxxiii-lxxxvi (English translation).

88 "Apparently not identical with the ms. which Dr Badger has quoted in his Nestorians, Vol. I., pp. 238 sqq." (W. Wright, A Catalogue of the Syriac Manuscripts Preserved in the Library of the University of Cambridge, Vol. 2, Cambridge, p. 1214). 


\section{Kazan 4}

The Central Scientific Library of the Kazan Scientific Center of the Russian Academy of Sciences (Kazan, Tatarstan, Russia), ms. 4 (Oriental collection). Kept in the library since before 1952, when it was researched by N.V. Pigulevskaya. ${ }^{89}$ Title: sedrā harzāa $\bar{a}$ 'The Book of Amulets' ${ }^{90}$ Paper, 72 leaves, bound, $8.8 \times 5.8 \mathrm{~cm}$. Text block $8.4 \times 4.8 \mathrm{~cm}$, includes 14 lines. $5^{1}$ chapters, 7 illustrations. Date and place: 1735 , village Sequnes, Nordus (Hakkari, Turkey), according to the colophon (f. 7or). Creator: the priest Markos, son of Shem 'on Saqnaya (ibid.). The manuscript exhibits a close affinity to ms. 5 in the Sado collection of Syriac manuscripts in Saint-Petersburg. ${ }^{91}$ Publication: A.C. Нуруллина (Черкашина), Сирийские заклинания. Literature: Гараева, “Рукопись сирийская".

89 Н. Гараева, "Рукопись сирийская, содержит заклинания и молитвы ... [A Syriac Manuscript, Contains Charms and Prayers ...]," Гасырлар авазы/Эхо веков, 32/33 (2003), c. 48 .

90 Lit.: "amuletic book".

91 G. Kessel and H. Teule, "The Mikhail Sado Collection of Syriac Manuscripts in St. Petersburg," in: Eastern Christians and their Written Heritage. Manuscripts, Scribes and Context (Eastern Christian Studies, 14), eds. J.P. Monferrer-Sala, H.G.B. Teule and S. Torallas Tovar, Leuven, 2012, pp. 43-76. For the discussion of parallels between mss. Kazan 4 and Sado 5 see: A.С. Нуруллина (Черкашина), Сирийские заклинания как продолжение арамейской заклинательной традииии поздней античности: исследование на материале рукописи ЦНБ КНЦ РАН 4. Дипломная работа. [Syriac Charms as Continuation of the Aramaic Magical Tradition: A Research Based on the Manuscript CNB KNC RAN 4. MA Thesis]. Москва, РГГУ, 2012. 